\title{
KALLIMACHOS ZEUS-HIMNUSZÁNAK EPILÓGUSA ÉS KOLOPHÓNI XENOPHANÉS*
}

\begin{abstract}
A következő elemzést az a megfigyelés indokolja, hogy Kallimachos Zeus-himnuszának epilógusa (h. 1. 91 sk.) utal az archaikus költő-filozófus Xenophanés egyik töredékére (fr. 34.1 sk.). Hogy ez eleddig senkinek sem tünt fel, annak tudható be, hogy Xenophanés töredékét több szerző idézi különféle változatban, Kallimachos pedig nem arra a szövegre utal, amelyik ma elfogadottnak tekinthetö, hanem arra, melyet Plutarchos (de aud. poet. 2.17 E) őrzött meg nekünk. Ez az észrevétel vezet tovább az allúzió szerepének vizsgálatához, amelyben a vendégszöveg a himnikus formakinccsel ötvöződik.
\end{abstract}

Kulcsszavak: Kallimachos, Xenophanés, allúzió, szöveghagyomány, himnikus költészet

Kallimachos himnuszköltészetének egyik avatott értelmezője arra a kérdésre, vajon miért írt a hellénisztikus költő himnuszokat, ezt a választ adta: „Miért ne?” A válasz csak látszólag semmitmondó. Kifejezésre jut benne Kallimachos korának igénye, hogy a költő a régi irodalmi müfajokat új tartalommal telítse. A himnusz müfaja nem hiányozhatott a sorból, hiszen ennek „darulába” (idegen szóval pedigréje) egészen Homérosig nyúlt vissza, legalábbis a hagyomány szerint, mely a chiosi dalnokot tette meg egy egész himnusz-corpus szerzőjének. Az alexandriai költő erre a szövegtestre építette fel a maga hat himnuszt számláló remeklését, mely fölényesen ismeri és némi ironizáló, játékos kedvü távolságtartással alkalmazza is a himnikus költészet müfaji konvencióit.

A hagyomány egy bizonyos ágának felidézése történhet a jól ismert költői allúziók segítségével vagy - ami ritkább, mert sokkal egyértelmübb - idézetek formájában. Kallimachos első himnusza, melynek címzettje Zeus, tartalmaz például két nevezetes idézetet, melyeket Pfeiffer kiadása idézőjelbe is helyez, és az apparátusban megadja a forrást: az

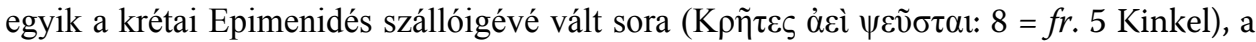

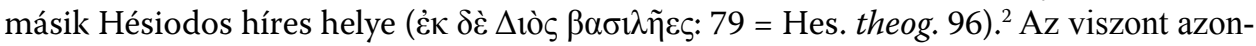

\footnotetext{
"Munkám során az MTA Bolyai János Kutatói Ösztöndíja támogatását élveztem. Köszönöm a Magyar Ókortudományi Társaság Archaikus és hellénisztikus. Xenophanés Kallimachos Zeus-himnuszában című felolvasásom meghallgatására 2015. december 18-án összegyűlt közönségének a kritikus megjegyzéseket, melyekkel dolgozatom továbbgondolására ösztönöztek.

1 M. W. Haslam: Callimachus' Hymns. In: M. A. Harder - R. F. Regtuit - G. C. Wakker (edd.): Callimachus. (Hellenistica Groningana 1) Groningen 1993. 125.

2 Az idézet definíciójához a hellénisztikus allúziós technika összefüggésében és a Hésiodos-félsor elemzéséhez a Zeus-himnuszban vö. P. Bing: The Well-Read Muse. Present and Past in Callimachus and the Hellenistic Poets. (Hypomnemata. Untersuchungen zur Antike und ihrem Nachleben 90) Göttingen 1988. 76-83.
} 
nal szemet szúrhat, hogy egyik sem a homérosi himnuszokból származó idézet, ami kézenfekvő volna, hanem más müfajú költeményekből. Kallimachos egyik meghatározó vonása ugyanis, hogy kerüli a megszokottat, kézenfekvőt, és keresi a meglepőt, zavarba ejtőt, ${ }^{3}$ ami tulajdonképpen minden modern müvészet sajátja, és Kallimachos kétségtelenül modernként viszonyul akár az archaikus, akár a klasszikus kor irodalmához. Továbbá a hellénisztikus irodalomesztétika egyik fontos követelménye a polyeideia, mely nemcsak azt jelenti, hogy a költő minél több müfajban kipróbálja magát, hanem hogy az egyes müfajokon belül is ötvözi, keveri a müfajok stílusjegyeit. ${ }^{4}$

Így talán kevésbé fog megdöbbentően hatni, ha azt állítom, hogy a Zeus-himnusz befejező passzusában Kallimachos az archaikus költő-filozófust, Xenophanést idézi. „Miért ne?” - mondhatná erre is az olvasó, aki már megszokta, hogy Kallimachosnál bármi lehetséges. Ennél azonban körültekintőbb elemzést érdemel ez az utalás, annál is inkább, mert mindezidáig nem vették észre, ami - idézetről lévén szó - meglehetősen szokatlan, majdhogynem hihetetlen. Ennek kézenfekvő okára azonnal fény derül. Lássuk először a két szöveghelyet.

Xenophan. fr. 35. 1-4 G-P (= 34 D-K):

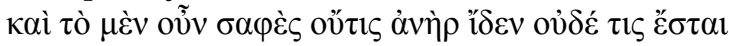

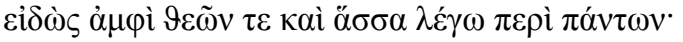

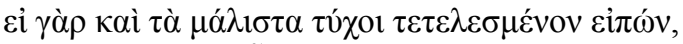

$\alpha$ ${ }^{\prime} \tau$ ò

$S$ biztosat pedig senki ember sem tudott s nem is fog tudni az istenekröl s mindarról, amiröl szólani fogok; még ha ugyanis a legnagyobb mértékben sikerül is neki kifogástalanul szólni, mégsem fog tudni a szó szoros értelmében, csak vélekedés az, ami mindenre vonatkozik.

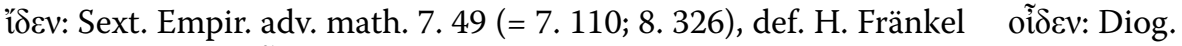
Laert. 9. $72 \mathrm{~B}^{\mathrm{ac}} \mathrm{F}^{\mathrm{ac}} \mathrm{P}^{\mathrm{ac}} \quad \varepsilon \tilde{i} \delta \varepsilon v$ Diog. Laert. 9.72 COW $\gamma \varepsilon \dot{\varepsilon} \varepsilon \tau$ ' Plut. de aud. poet. 2. 17E, retinuerunt Karsten, $\mathrm{D}^{2}$ alii, adversante Wil. Kl. Schr. IV 40

Kall. h. 1. 91-93:

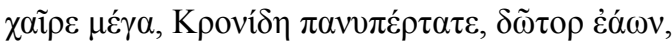

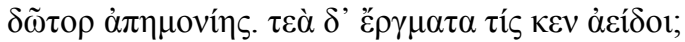

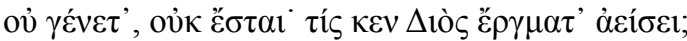

${ }^{3}$ B. Snell: Die Entdeckung des Geistes. Studien zur Entstehung des europäischen Denkens bei den Griechen. Göttingen 19754.248: Statt des allgemein Bekannten bringt er die seltene Variante, die überrascht, und treibt allerlei Spiel und Schabernack, Verstecken und Rätselraten. Vor allem ist sein Witz wach, Dinge zu verbinden, die ursprünglich nichts miteinander zu tun hatten.

4 Vö. N. Hopkinson: Callimachus' Hymn to Zeus. CQ 34 (1984) 147 sk. 
Üdvöz' légy ezerszer, Kronos leghatalmasabb sarja, jó dolgok adományozója, gondtalanság adója! Ki lenne képes tetteidet megénekelni? Nem született és nem is lesz az az ember! Ki tudná Zeus tetteit megénekelni?

A Xenophanés-idézet a kolophóni költő agnósztikus filozófiai álláspontot tükröző megnyilatkozásaként tett szert némi ismertségre, ami elég volt ahhoz, hogy a négy sor három császárkori szerzőnél idézetként fennmaradjon. ${ }^{5}$ Xenophanés ebben a töredékében az emberi megismerés határairól elmélkedik, és megállapítja, hogy biztosat ( $\sigma \alpha \varphi \varepsilon ́ s)$ egyetlen halandó sem tudhat az istenek és a mindenség természetéről, csupán vélekedését, feltételezéseit fogalmazhatja meg ezekkel kapcsolatban. Könnyen elképzelhető, hogy ez a passzus eredetileg Xenophanés természetről szóló tankölteménye bevezetőjében foglalt helyet.

Ha megnézzük Gentili és Prato elégikusokat tartalmazó szövegkiadásának apparátusát, azonnal választ kapunk kérdésünkre, miért nem ismerte fel a Kallimachos-kutatás a Xenophanés-idézetet a Zeus-himnusz epilogusában. Azért nem, mert a hellénisztikus költőfejedelem nem a Sextus Empiricusnak és Diogenés Laertiosnak köszönhető formában ismerte, hanem abban, amelyet Plutarchos De audiendis poetis (Hogyan hallgassa és értelmezze az ifjú a régi költóket?) címủ esszéje rögzített. Az olasz kiadók Karsten, Diehl és mások felfogásával szemben, Wilamowitz támogatásával a hátuk mögött, a $\gamma \varepsilon ́ v \varepsilon \tau$ ' igealak helyett a metrikailag egyenértékủ ỉosv-t olvasták, s így a kallimachosi idézet valóban felismerhetetlenné válik. Itt természetesen nem tisztünk állást foglalni

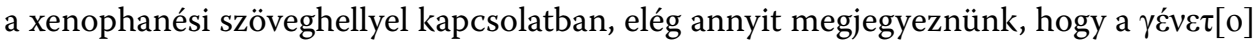

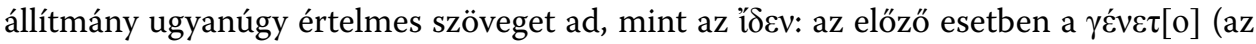

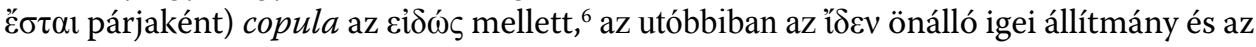

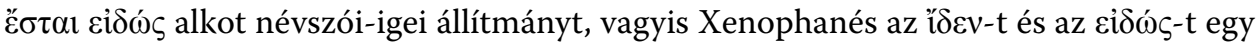
tőből származtatja, ami a tudományos etimológia által igazolt helyes nyelvi intuíció, és a tudást ( $\varepsilon i \delta \omega ́ \varsigma)$ a látásból ('í $\delta \varepsilon v)$ eredezteti. ${ }^{7}$ Ha most Plutarchos Xenophanés-szövegvariánsát és Kallimachos himnuszának majdhogynem befejező sorait egymás mellé helyezzük, világossá válik a nagyfokú egyezés:

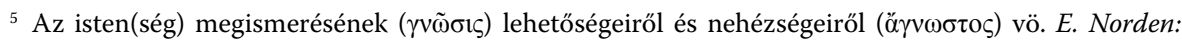
Agnostos Theos. Untersuchungen zur Formengeschichte religiöser Rede. Leipzig - Berlin 1913. 56-95, aki a transzcendencia megismerhetetlenségét jellegzetesen nem-görög vonásnak tekinti és a keleti hatásokat befogadó gnózisból vezeti le (83-87; vö. azonban a kivételeket [87-95], melyekhez adalékként Hom. E 127 sk.).

${ }^{6}$ A szerkezethez további példákkal vö. L. Woodbury: The Epilogue of Pindar's Second Pythian. TAPhA 76 (1945) $18 \mathrm{sk}$.

${ }^{7}$ Xenophanés empirikus (szemtanúként szerzett) ismeretelméletéhez vö. H. Fränkel: Dichtung und Philosophie des frühen Griechentums. Eine Geschichte der griechischen Epik, Lyrik und Prosa bis zur Mitte des fünften Jahrhunderts. München $1962^{2}$. 383. A töredék szövegéhez és értelmezéséhez vö. H. Fränkel:

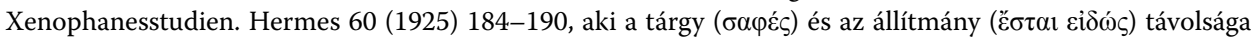
miatt tartja a $\gamma \varepsilon \dot{v} \varepsilon \tau$ ' alakot hibásnak. 
Xenophan. fr. 35.1 sk.:

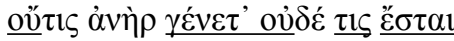

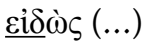

Kall. h. 1. 91 sk.:

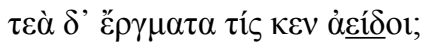

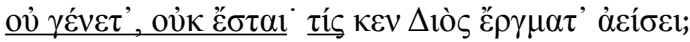

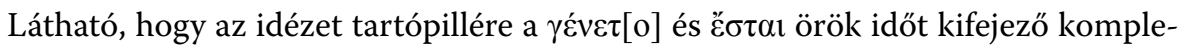
menter párosa tagadva („nem volt” - „nem lesz” = „sohasem”), ${ }^{8}$ ahogy az Xenophanésnál is ugyanezzel a tartalommal és ugyanebben a formában - a második tagadószó kappa hangját leszámítva - megtalálható. Ezen kívül olybá tünik, mintha Kallimachos a Xenop-

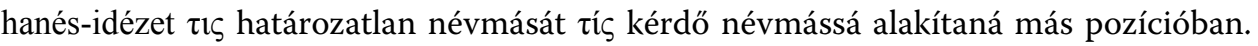

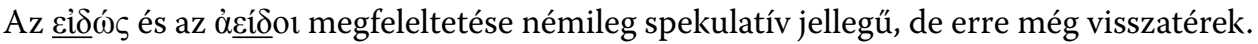
Az idézet minimalista, ám a kallimachosi művészetfelfogás is az, a magam részéről tehát nem táplálok kétséget az idézet ténye felöl.

Ebből az a rendkívül szerény történeti következtetés adódik, hogy Kallimachos és Plutarchos olyan Xenophanés-hagyományt ismerhettek, mely azonos archetípusból ered. Nem tudni, hogy ez valamely többé-kevésbé teljes Xenophanés-kézirat volt, vagy már ők is csak idézetként olvasták a töredéket. Kallimachos esetében - ismerve az alexandriai könyvtár gazdagságát - hajlanánk az előbbire, Plutarchosnál az utóbbira. ${ }^{9}$ Mindenesetre a Xenophanés-szövegkiadásban Plutarchos neve elött fel kellene tüntetni

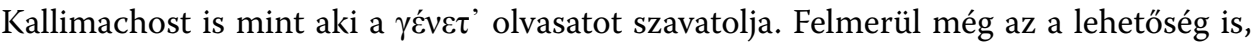

${ }^{8}$ A két ige az idők teljességét kifejező rétorikai alakzatként (vö. E. Kemmer: Die polare Ausdrucksweise

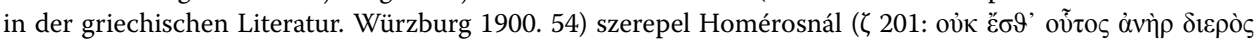

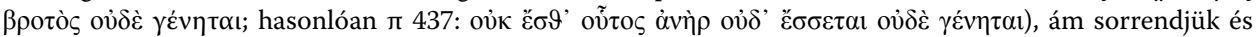
alakjuk eltérő. Vö. G. R. McLennan: Callimachus: Hymn to Zeus. Introduction and Commentary. Roma 1977. 129 ad loc. Hopkinson: i. m. (4. jegyz., 147, 49. jegyz.) a kifejezés toposz jellegét hangsúlyozza (Even more than at the beginning of the hymn, anaphora and paired clauses luxuriate [kiemelés tölem - A. Zs.]). Bolonyai Gábornak tartozom köszönettel, amiért felhívta figyelmemet két különbségre: az egyik a Xenophanésnál meg-

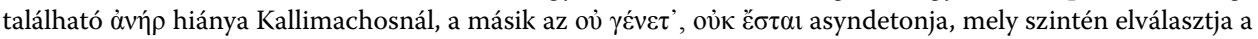
kallimachosi megfogalmazást a homérosi és xenophanési előzményektől. A költő ezzel (feltehetőleg öntudatlanul) arra az ősi indoeurópai alakzatra nyúlt vissza, mely poláris kifejezéseket kötőszó nélkül kapcsolt össze, így érzékeltetve a látszólagos kettősségből kirajzolódó egységet (vö. P. Chantraine: Un tour archaique chez Pindare [Ol. VI, 78; Pyth. IV, 217] RPh 27 [1953] 16-20). Ami az òví $\rho-t$ illeti, mivel a kallimachosi tíç is ha-

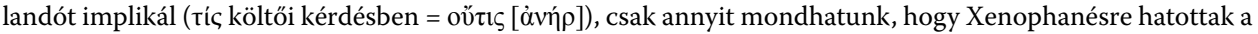
fent idézett homérosi helyek. Ez a hatás a plutarchosi szövegolvasatot támogatja, mely ettől függetlenül nagy valószínűséggel mégis hibás (vö. 9. jegyz.). Tény viszont, hogy a kallimachosi megfogalmazáshoz Plutarchos

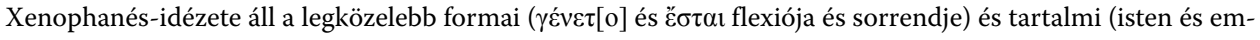
ber viszonya) szemszögből.

${ }^{9}$ Fränkel: i. m. (7. jegyz. [1925]) 185 gyanúja, hogy Plutarchos emlékezetből és a homérosi fordulatok

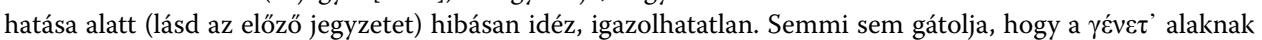

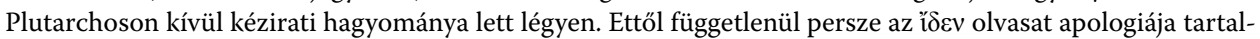
mi-stilisztikai érvek alapján meggyőző marad. 


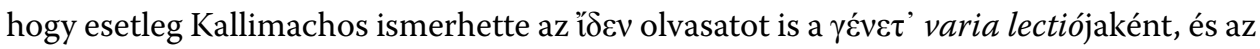
idézettel állást kívánt foglalni, illetve sugallni e filológiai kérdésben. ${ }^{10} \mathrm{Ez}$ azonban merő spekuláció. Helyette inkább vizsgáljuk meg, milyen célzattal helyezhette el Kallimachos a preszókratikus költö-filozófus idézetét Zeus-himnusza végén.

A passzust megelőző soroknak (89 sk.) szintén központi gondolata az istenség, Zeus mindenek feletti hatalma, mellyel senki ember nem veheti fel a versenyt. A halandó költő korlátozott képességére való hivatkozás ezt a gondolatkört folytatja. A felszíni tartalmi kapcsolat így kézenfekvő: ahogy Xenophanés szerint az emberi megismerőképesség korlátozott, főként az istenség vonatkozásában, úgy Kallimachos szerint az ember dicsőítő képessége véges, ami alkalmatlanná teszi arra, hogy az istent (Zeust) megénekelje. A hellénisztikus költő mintha Xenophanés általános kijelentését vonatkoztatná - a fortiori - az ember szűkebb tevékenységi körére, az istent magasztaló dalnok szerepkörére. ${ }^{11}$ Ami tehát Xenophanésnál elvont (ha úgy tetszik, filozófiai) tudás,

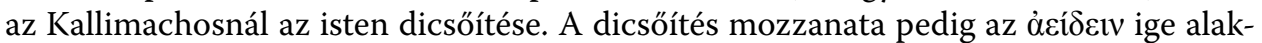
jaiban jut kifejezésre. Felmerül annak lehetősége, hogy Kallimachos itt a xenophanési

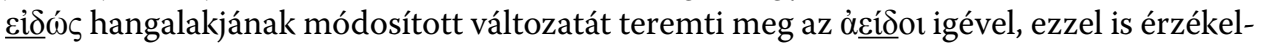
tetve a két episztemológiai szint, a megismerés és a dicsőítés megfelelését.

Míg ez némileg bizonytalan, ha vonzó feltételezés is, aligha lehet kétséges, hogy

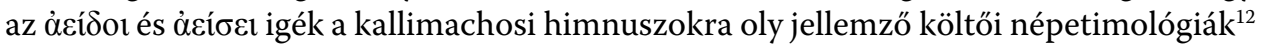

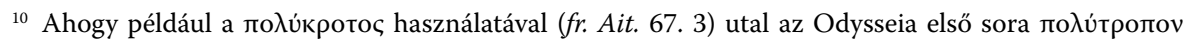
jelzőjét övező zétémára. Vö. M. A. Harder: Callimachus: Aitia, II: Commentary. Oxford 2012. 550 sk. ad fr. 67. 3 .

11 Ez a versvégi recusatio egyébként rokonítja a himnuszt az Apollónhoz intézett második befejezésével, ahol a költő a megszemélyesített $\phi$ 0óvoc elhárításával (105-113) mentegetőzik a himnusz rövidségéért. Vö. A. Köhnken: Apollo's Retort to Envy's Criticism (Two Questions of Relevance in Callimachus, Hymn. 2, 105ff.). AJPh 102 (1981) 417 sk., főként 418, 35. jegyz.). A Zeus-himnuszban a költő korlátozott képességei adják az igazolás alapját. Vö. K. Ziegler: Zum Zeushymnus des Kallimachos. RhM 68 (1913) 350: Da nun der Dichter zum Entgelt für seine Leistung, den Hymnus, von der Gunst des Gottes etwas erbitten will, macht er sich klar, dass er ja das, was ein Hymnus zu leisten hat, noch gar nicht geleistet hat, dass er nichts von den Taten des Gottes gesungen hat.

12 A költői etimológiák alexandriai hagyományához vö. J. J. O’Hara: True Names. Vergil and the Alexandrian Tradition of Etymological Wordplay. Ann Arbor 1996. 21-42. Kallimachos például a második

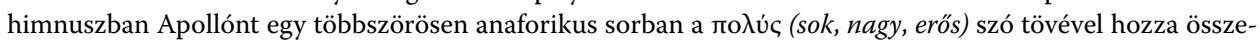

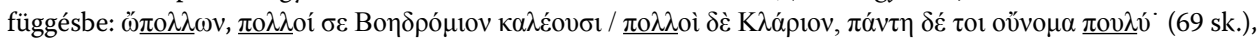

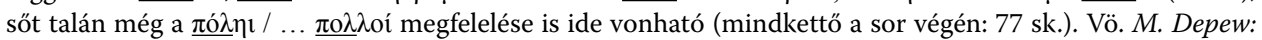
Gender, Power, and Poetics in Callimachus' Book of Hymns. In: M. A. Harder - R. F. Regtuit - G. C. Wakker (edd.): Callimachus II (Hellenistica Groningana 7). Leuven - Paris 2004. 123. Ez természetesen nem akadálya annak, hogy a vers végén Apollón az új esztétikai program értelmében ḋ- $\pi$ o $\lambda$ $\varsigma_{-}$- („Nem Óriás”) jelentsen,

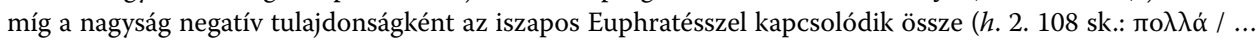
по入入óv). Így R. Hunter - Th. Fuhrer: Imaginary Gods? Poetic Theology in the Hymns of Callimachus. In: F. Montinari - L. Lehnus (edd.): Callimaque (Entretiens sur l'antiquité classique 48). Genève 2002. 152. Sőt a 101 sk. sorokból még egy további etimológia is kibontakozni látszik, ezúttal Apollón nyilas művészetét foglal-

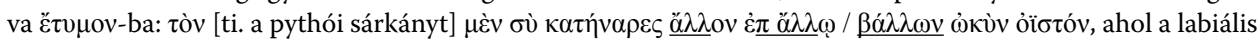
$\pi / \beta$ hang és az $\alpha \lambda \lambda \omega v$ elem adják ki az isten nevét. Ezt az etimológiát Platón is ismeri, aki Apollónt többek között A\&ıßó $\lambda \lambda \omega v$-ként értelmezi (Kratyl. 405C). Végezetül a himnusz 103. sorában a ị̀ ì̀ đåñov magyarázatát 
egyikét rejtik. Az ige első szótagja ugyanis az ảeí hátározószóval hozható összefüggésbe, ami az ének azon képességét fejezi ki, hogy örök emléket állítson az örök isteneknek. ${ }^{13}$ A fordulat Hésiodostól származik, akit a Múzsák parancsa utasít az örökké élő istenek

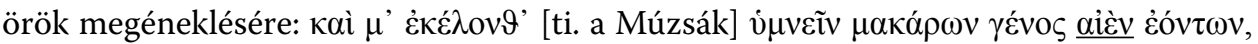

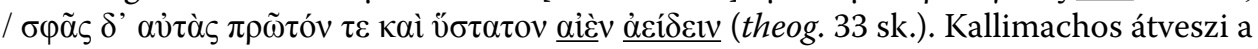
hésiodosi szójátékot, ám ellentétes értelemben: felfogásában a halandó ember nem képes felérni - költeményével sem - az isten örökkévalóságához, képtelen $\alpha \varepsilon i ́-\delta \varepsilon v v$, azaz örökkévaló emléket állítani az örökkévalónak. Hogy az ige és a határozó ilyen költői kapcsolata nem képzelgés, azt a vers prológusa bizonyítja. Keretes szerkezetről beszélhetünk tehát, ám míg az epilógus a kétely hangján szól, a bevezetőt a kezdet lelkesedése hatja át:

Kall. $h .1 .1$ sk.:

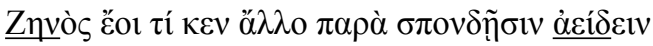

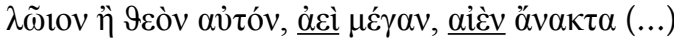

9:

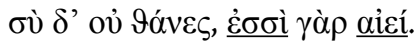

Aligha véletlen, hogy a prológus első szava Zeus (Zๆvós), jelezve, hogy ő az első dolog, amely eszébe juthat a dalnoknak. A prológus záró sorában (9) pedig válaszként a

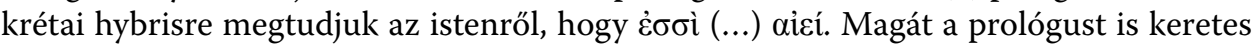

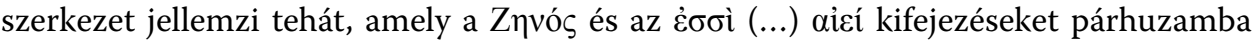

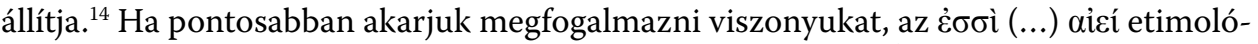

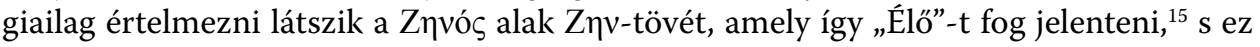
igen lényeges üzenet a haláláról szóló híresztelésekkel ( 8 sk.) szemben.

Az isten örökkévalósága pedig - ahogy az epilógusban is - rögtön összekapcsolódik az ének/himnusz múlhatatlanságával ( $\alpha \varepsilon i ́ \delta \varepsilon ı v \sim \alpha \dot{\alpha} \varepsilon i ́ \sim \alpha \grave{\varepsilon} v) .{ }^{16} \mathrm{Az}$ is tudatos elrendezés

láthatjuk az utána álló ̌ı $\beta \varepsilon ́ \lambda o \varsigma(\sim \underline{\pi \alpha i ́ \omega)}$ buzdításban. Vö. C. Meillier: Callimaque et son temps. Recherches sur la carrière et la condition d'un écrivain à l'époque des premiers Lagides. Lille 1979. 89. Lásd még Pind.

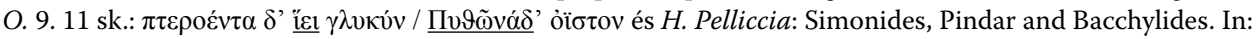
F. Budelmann (ed.): The Cambridge Companion to Greek Lyric. Cambridge 2009, 256), vagyis a vers epilógusa hemzseg a költői etimológiáktól.

${ }^{13}$ Vö. K. Keyßner: Gottesvorstellung und Lebensauffassung im griechischen Hymnos (Würzburger Studien zur Altertumswissenschaft 2). Stuttgart 1932. 39-44.

${ }^{14}$ A keretező szerkezethez vö. $h$. 2. 65: Фõ̃ßo szavakkal chiazmussá egészül ki.

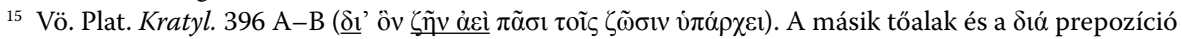

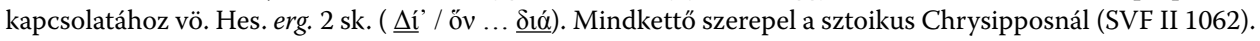
Lásd még Ael. Arist. or. 43. 23 Keil, valamint Norden: i. m. (5. jegyz.) 22, 164, 4. jegyz., 172 és 259, 1 . jegyz.

16 Vö. Hopkinson: i. m. (4. jegyz.) 139-141 (további példái Hom. $h$. 10. 1-3, Theokr. 16. 1-4) és $M$. Cuypers: Prince and Principle: The Philosophy of Callimachus' Hymn to Zeus. In: M. A. Harder - R. F. Regtuit - G. C. Wakker (edd.): Callimachus II (Hellenistica Groningana 7). Leuven - Paris 2004. 105. Egy másik feltűnő etimológiai szójáték a himnuszban Árkádia szárazságához kapcsolódik, amiért lakosai neve 
műve lehet, hogy az első sor első szava az örökkön élő isten, utolsó szava az örök dicsőítés. Ugyanez a szójáték bukkan fel Kallimachosnál az Artemis-himnusz egyik invokáci-

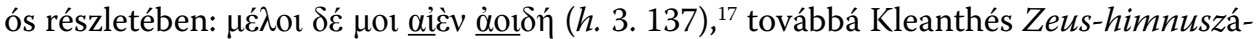

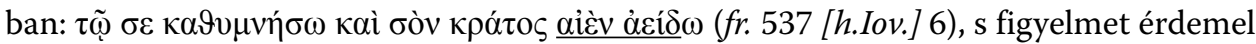
egy Lucretius-hely, mely lehet akár annak a dokumentuma is, hogy a római költő, aki szintén kedveli a költői etimológiákat, éppen Kallimachosból ihletődött:

Lucr. 1. 117-121:

Ennius (...), qui primus amoeno

detulit ex Helicone perenni fronde coronam, per gentis Italas hominum quae clara clueret; etsi praeterea tamen esse Acherusia templa Ennius aeternis exponit versibus edens (...)

Arra már korábban rámutattak, hogy Lucretius itt Ennius nevét a hangalaki hasonlóság alapján a perennis jelzővel kapcsolja össze. ${ }^{18}$ Azt azonban nem emelték ki, hogy a játék az örökkévalóság tövével a 121. sorban szemantikai síkon folytatódik. Lehetséges, hogy az aeternis versibus köszönhet valamit a Kallimachosnál világosan kimutat-

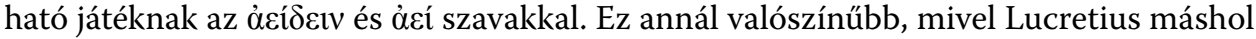
egyértelműen tanúságot tesz a Zeus-himnusz ismeretéről és az ebben felbukkanó költői etimológiák továbbgondolásáról. ${ }^{19}$

Visszatérünk Kallimachos himnuszához. A Xenophanés-idézettel a költő az előbbi okfejtés fényében azt is sugallja, hogy az ember halandó (nem ảcí) volta okolható azért, hogy nem tud felnőni az örökkévaló isten lényegéhez, ezért azt sem megismerni

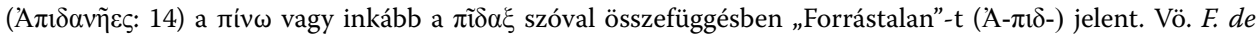

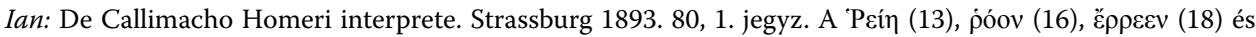

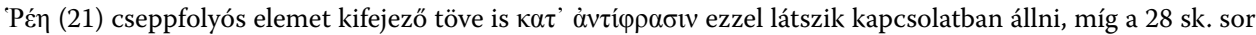

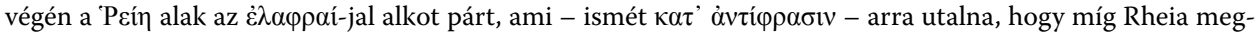

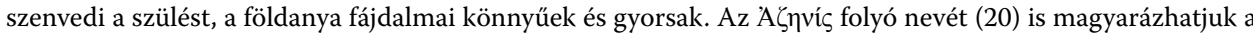

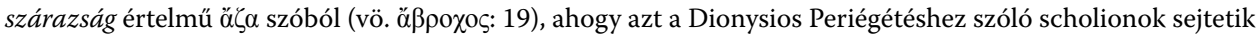
(Pfeiffer II 2 in apparatu loc. par.), ám lehet, hogy közelebb járunk Kallimachos gondolatmenetéhez, ha itt is a

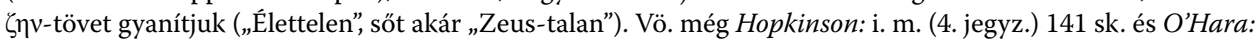
i. m. (12. jegyz.) 33 .

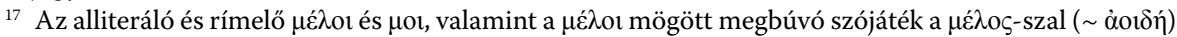
szintén említésre méltó.

18 Vö. M. R. Gale: Etymological Wordplay and Poetic Succession in Lucretius. CPh 96 (2001) 168 korábbi irodalommal.

${ }^{19}$ Vö. McLennan: i. m. (8. jegyz.) 87 sk., R. D. Brown: Lucretius and Callimachus, ICS 7 (1982) 86

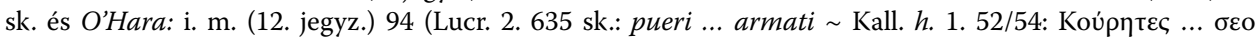
коupí(оvтоৎ). Lucretius költészetének kapcsolatához a hellénisztikus irodalmi hagyománnyal vö. E. J. Kenney: Doctus Lucretius. Mnemosyne 23 (1970) 366-392 (= In: C. J. Classen [ed.]: Probleme der Lukrezforschung [Olms Studien 18] Olms 1986. 237-265 [Addenda kíséretében]). 


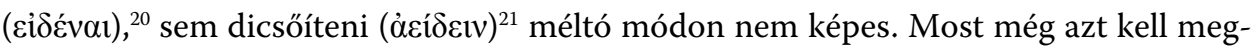
vizsgálnunk, hogyan illeszkedik ez a gondolatmenet a himnusz müfaji követelményeihez, avagy milyen új játékteret nyit meg a müfaji konvenciók összefüggésében. A dalnok alkalmatlansága, kicsinysége tulajdonképpen tökéletesen himnikus szabású téma. ${ }^{22}$ Klasszikus archetípusa a homérosi hajókatalógus Múzsa-invokációja:

Hom. B 484-492:

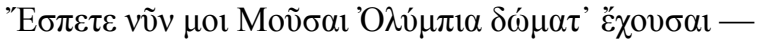

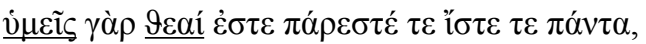

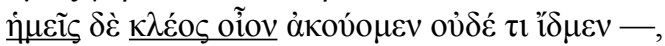

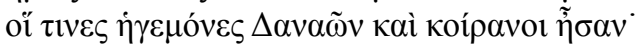

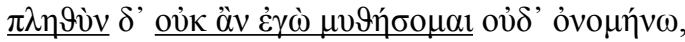

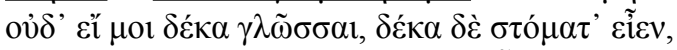



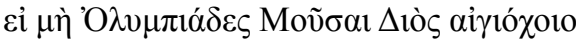

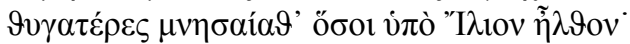

Ebben a Múzsák biztos, mert közvetlen szemtanúságon alapuló tudása ( $\pi \alpha ́ \rho \varepsilon \sigma \tau \varepsilon \dot{\varepsilon}$ $\tau \varepsilon$ í $\sigma \tau \varepsilon \tau \varepsilon$ : szójáték a létige, a látás és tudás tövével) áll szemben az ember bizonytalan, mert másodkézből származó értesüléseivel ( $\left.\kappa \lambda \varepsilon \varepsilon_{0} \varsigma\right) .{ }^{23} \mathrm{Az}$ ember és isten közötti ellentét tehát szinte xenophanési módon ismeretelméleti jellegű: a homérosi î $\sigma \tau \varepsilon$ az embertől

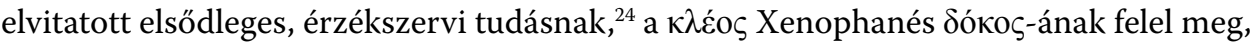
csak éppen itt nem az istenség megismerése a tét. Ám az ellentét nemcsak minőségbeli, hanem mennyiségi is. Míg a Múzsák mindentudók, az ember nem képes a mindenség teljes megismerésére, amit a $\pi \lambda \eta \vartheta v ́ v$ fejez ki, még akkor sem, ha fizikai képességei

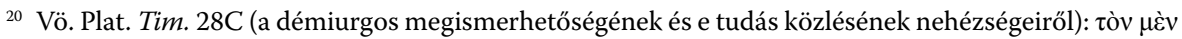

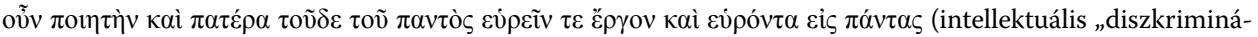

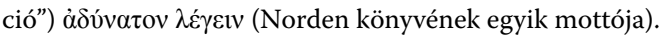

${ }^{21}$ Vö. Ael. Arist. or. 43. 2-4 Keil (prózahimnusz Zeus tiszteletére), melynek elején a szerző megvallja önnön kicsinységét, amely alkalmatlanná teszi a votum (Zeus dicsőítése) teljesítésére. Ennek ellenére megpróbálkozik vele, amihez a Múzsák segítségét kéri (6). Ugyanez a gondolat tér vissza a beszéd befejezésében

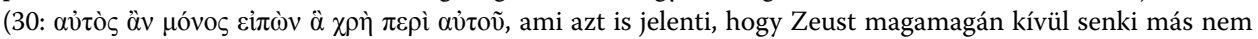
képes méltó módon dicsőíteni).

22 A motívumhoz (Bescheidenheitstopos / Unfähigkeitsbeteuerung) vö. Keyßner: i. m. (13. jegyz.) 86 (das Gefühl vollständiger Abhängigkeit von der göttlichen Macht [a kallimachosi szöveghellyel]), középkori utóéletéhez E. R. Curtius: Europäische Literatur und lateinisches Mittelalter. Tübingen-Basel $1993^{11} .412-414$ (Exkurs II: Devotionsformel und Demut).

${ }^{23}$ Theokritos (16. 1-4) erre a homérosi ellentétre hivatkozva hangoztatja, hogy míg a Múzsák dolga az

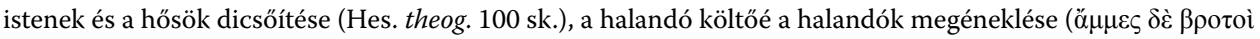

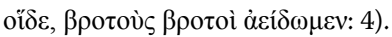

${ }^{24}$ Vö. Fränkel: i. m. (7. jegyz. [1925]) 186, 1. jegyz., aki a homérosi helyet a szemtanúsággal szerzett tudás összefüggésében idézi. Lásd még Snell: (3. jegyz.) 129 sk., aki szintén Homéros múzsainvokációjából kiindulva a Xenophanés-töredéket a görög ismeretelmélet kontextusában vizsgálja. 
természetellenes módon többszörösre növekednének is. ${ }^{25}$ Természetesen az invokáció feloldja ezt az ellentétet: a Múzsák segítsége pótolni fogja a feladat elvégzéséhez hiányzó erőt. A homérosi passzus kétféle alakváltozatban él tovább a himnikus költészetben. A $\pi \lambda \eta \vartheta u ́ \varsigma$ toposzát folytatják azok a szöveghelyek, melyek a tárgyban rejlő kimeríthetetlen lehetőségekre hivatkoznak. Ez - közelebb a homérosi előképhez - állhat az aporia jegyében, amikor a himnuszköltő kérdés(ek) formájában ${ }^{26}$ zavarodottságot és tanácstalanságot színlel a tárgy nyújtotta végtelen bőség láttán: ${ }^{27}$

Hom. h. Ap. 87-88:

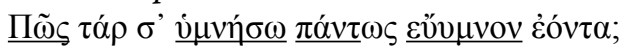

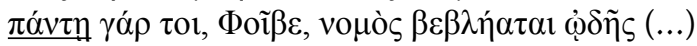

Ennek kallimachosi folytatása:

Kall. h. 1. 4:

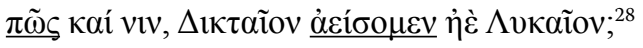

Kall. h. 4. 28 sk.:

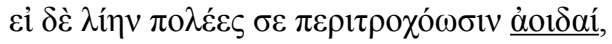

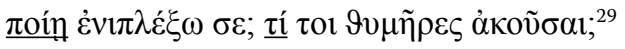

De megtalálható a kérdésforma például Theokritosnál is epikus hasonlatra emlékeztető képi anyaggal szemléltetve:

Theokr. 17. 7-12:

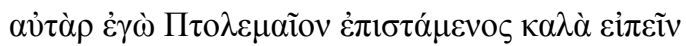

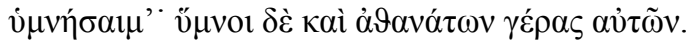

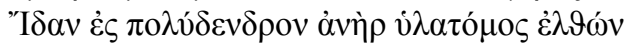

${ }^{25}$ A motívum utóéletéhez vö. Verg. georg. 2. 42-44 és Aen. 6. 625-627. A beszélőszervek megsokszorozásának motívuma bábáskodhatott Wolfram von Eschenbach Parzifal-prológusának alábbi passzusánál: $n u$ lât mîn eines wesen drî, / der ieslîcher sunder phlege / daz mîner künste widerwege: / dar zuo gehôrte wilder funt, / op si iu gerne taten kunt / daz ich iu eine künden wil. / si heten arbeite vil (I 4. 2-8).

${ }^{26}$ A kiegészítendő kérdéssel bevezetett bőségmotívumhoz vö. még Pind. O. 2. 2 és Paul Gerhardt Wie soll ich dich empfangen kezdetű egyházi himnuszát, ahol a strófa második fele ugyanúgy kér tudást és inspirációt Jézustól, mint a homérosi invokáció a Múzsáktól (Wie soll ich dich empfangen / Und wie begegn' ich dir? ) O aller Welt Verlangen, / O meiner Seelen Zier! / O Jesu, Jesu, setze / Mir selbst die Fackel bei, / Damit, was dich

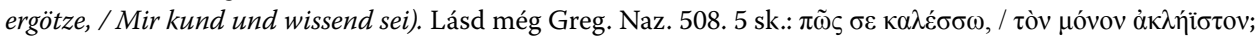
(egyik Isten-himnuszában) valamint Norden: i. m. (5. jegyz.) 152.

27 Vö. Hopkinson: i. m. (4. jegyz.) 140 (további példái: Aischyl. Ag. 783-786 [a halandó Agamemnón dicsőítése], Aristoph. Pax 520-526).

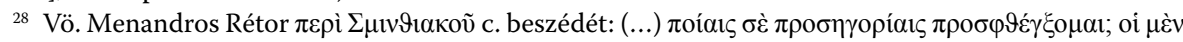

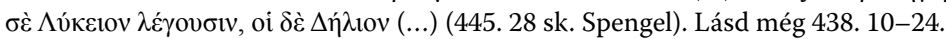

${ }^{29}$ Vö. Bing: i. m. (2 jegyz.) 112. 


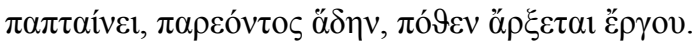

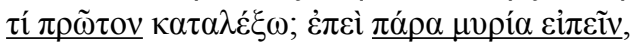

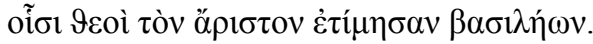

A motívum másik változata nem a bőségben rejlő zavart (embarras de richesse) hangsúlyozza, hanem éppen ellenkezőleg a könnyűséget, mellyel a himnuszköltő a tárgyán dicsérnivalót talál. Ennek visszatérő kifejezése (már a fent idézett homérosi Apol-

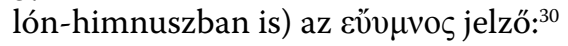

Kall. h. 2. 30 sk.:

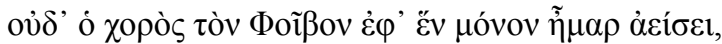

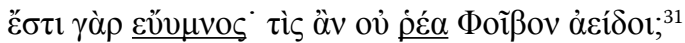

Kall. h. 4. 2-5:

$\tilde{\eta} \mu \grave{\varepsilon} \nu \alpha \ddot{\pi} \alpha \sigma \alpha \imath$

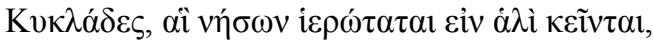

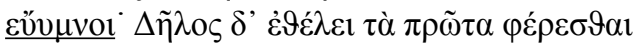

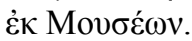

Sötétebb-moll tónusú hangszerelése ugyanennek a motívumnak az a változat, melyet Kallimachos a Zeus-himnusz végén használ. Itt az első variációnál tapasztalható kérdésforma („hogyan legyen képes az ember az isteni tökéletességet szavakba foglalni?") nem nyer feloldozást, a disszonancia kitartott marad - ami természetesen ugyanúgy a művészi hatáskeltés eszköze, mint bármelyik más alakzat. Ennek szép példája olvasható a már idézett római költő Epikurost dicsérő prológusában:

Lucr. 5. 1-12:

quis potis est dignum pollenti pectore carmen condere pro rerum maiestate hisque repertis? quisve valet verbis tantum, qui fingere laudes pro meritis eius possit, qui talia nobis pectore parta suo quaesitaque praemia liquit? nemo, ut opinor, erit mortali corpore cretus. nam si, ut ipsa petit maiestas cognita rerum, dicendum est, deus ille fuit, deus, inclyte Memmi, qui princeps vitae rationem invenit eam quae

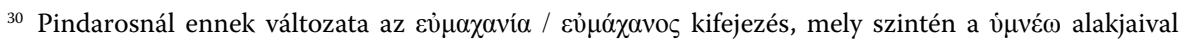
kapcsolódik össze (I. 4. 20 és - múzsai invokáció részeként - fr. 52h [Pai. 7b] 16).

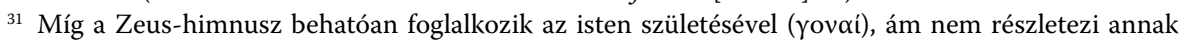
aretalogiáját, az Apollón-himnuszban a költő éppen ellentétes módszert követ, amely a bőséget hangsúlyozó alakzatot magyarázza. Vö. McLennan: i. m. (8. jegyz.) 130 ad h. 1. 93. 


\section{nunc appellatur sapientia, quique per artem \\ fluctibus e tantis vitam tantisque tenebris \\ in tam tranquillo et tam clara luce locavit.}

Köztudott, hogy Lucretius itt Ennius hatodik könyvének feltehetően szintén bevezető kérdésére utal (fr. 164 [174]: quis potis ingentis oras evolvere belli?). ${ }^{32}$ A lényeg azonban nem ez, hanem hogy mindketten a korlátolt költői erő toposzát aknázták ki. Lucretiusnál ráadásul ez a motívum kétszólamú. Az első két sorban emberfeletti vállalkozásnak tartja, hogy az ember a világegyetem csodáit méltó módon foglalja költeménybe. Ez valójában Xenophanés fragmentumának témája. A következő három sorban pedig hasonlóan emberpróbáló kihívásnak nevezi, hogy egy másik költő képes legyen azt dicsérni, aki erre képes volt. Nyilván senki ember (nemo ... mortali corpore cretus) sem alkalmas erre. Ez a Zeus-himnusz epilogusának gondolata. Ez a másik, eleve kudarcra ítélt költő természetesen önmaga, Lucretius, az első pedig, akit magasztalni kell(enne), Epikuros, akiről a következő sorokból kiderül, hogy neki sikerült a lehetetlen, a dolgok fenséges természetének méltó megéneklése, amiért méltán lehet istennek nevezni (deus, nyomatékosan kétszer is megismételve; vö. még 49-54). ${ }^{33} \mathrm{Ez}$ a fordulat egyébként nemcsak Lucretius nagyrabecsülésének jeleként értelmezhető (a hibás istenképtől megszabadító ember maga is már-már isten), hanem úgy is, hogy ezzel a költő a motívum himnikus eredetére is rávilágít, ahol a megénekelt kötelező módon valamely isten.

Kétség nem férhet hozzá: amikor Kallimachos a Zeus-himnusz 91 sk. sorában a nemes feladatra való képtelenségét hangoztatja, a himnikus költészet eszköztárának egyik bevett fordulatát alkalmazza. ${ }^{34}$ Eredetisége azonban nem tagadható. Ehhez a himnikus motívum filozófiai bázisát, emberi megismerés és isteni tökéletesség összeütközését helyezi előtérbe, s ezzel a megszokott fordulatot visszavezeti homérosi archetípusára, ahol szintén az emberi és isteni tudás ellentéte szülte a dalnok aggályait. Kallimachos tehát nemcsak használja a toposzt, hanem reflektál is annak eredetére. Ez a müfaji tudatosság egyik megkülönböztető jellemzője költőnknek. Hogy ezt a műfaji analízist a filozófiai mondanivaló felerősítésével végzi el, s ebből a célból a motívumot egy költő-filozófus, Xenophanés töredékébe bújtatja, ismét hellénisztikus vonás, és a polyeideiára való törekvéssel magyarázható. Xenophanés elsősorban mint a silloi-müfajának megalapítója természetesen számot tarthatott a hellénisztikus költők érdeklődésére, főként phliusi Timónéra. ${ }^{35}$ Talán Kallimachos iambosaira is hatással lehetett, de ez nem mutatható ki

${ }^{32}$ Vö. O. Skutsch: The Annals of Quintus Ennius. Edited with Introduction and Commentary. Oxford 1986. 329 ad loc.

${ }^{33}$ Hasonló teljesítmény előtti csodálatának ad hangot Leónidas is Aratosnak hódoló epigrammájában (Anth. Graec. 9. 25). A költemény utolsó distichonja (5 sk.) a költőt Zeus után másodikként magasztalja.

${ }^{34}$ Éppen a fordulat topikus voltát ismeri félre $U$. von Wilamowitz-Moellendorff: Hellenistische Dichtung in der Zeit des Kallimachos II: Interpretationen. Berlin 1924. 11, amikor azzal magyarázza, hogy valójában nem is Zeusra, hanem Ptolemaiosra kell érteni, aki nem tud a megénekléshez szükséges mennyiségü tettet felmutatni.

35 Vö. Bing: i. m. (2. jegyz) 71 sk. 
egyértelműen. Összességében megállapítható, hogy Xenophanés eddig nem szerepelt Kallimachos előképei között. ${ }^{36}$

Felvetődhet még a kérdés, hogy a filozófus-költő idézésével Kallimachos esetleg valamilyen rejtett, ám következetesen végigvitt filozófiai programot akart olvasóival közölni. Cuypers ugyanis amellett érvelt korábban idézett cikkében, hogy a hellénisztikus költő többek között rhodosi Antagoras Erós-költeményének ( $f r$. 1 Powell) idézésével ${ }^{37}$ az akadémiai szkepszis nézeteit hangoztatta olyan témakörben, amely a rivális filozófiai iskola, a sztoikusok egyik reprezentatív „iskolai” gyakorlata volt (Zeus mint a $\lambda$ ó kifejeződése). ${ }^{38} \mathrm{Az}$ a tényállás azonban, hogy Lucretiusnál a szerénységi alakzat meglehetősen pontos párhuzamára bukkantunk, óvatosságra int. Hiszen a római költő egészen más filozófiai iskola szószólója, ami azt jelenti, hogy a motívumazonosság nem a filozófiai rendszer rokonságával függ össze, hanem a himnikus formakinccsel, melyből a filozófiai tartalomtól függetlenül mindkét költő egyaránt merített.

Annak viszont talán van némi alapja, hogy a himnusz befejezésében a sztoikus dogmával vitatkozó állásfoglalást lássunk, ${ }^{39}$ anélkül persze, hogy Kallimachosnak dogmatikus filozófiai programot akarnánk tulajdonítani, aki a filozófiai hagyományokat is ugyanolyan játékos könnyedséggel kezeli és keveri, mint az irodalmi örökséget. ${ }^{40}$ A megismerés felfüggesztése ( $\dot{\varepsilon} \pi \circ \chi \eta ́)$ a szkeptikus irányzat jellegzetes ismeretelméle-

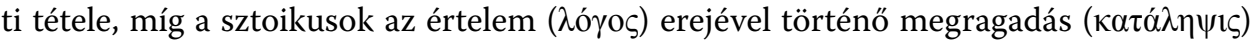

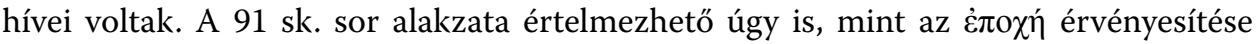
Zeus fogalmának megragadása kapcsán. Ezenkívül mintha a megéneklés lehetőségének visszautasításával Kallimachos a sztoikus Zeus-dicsőítés optimizmusa ellen emelne

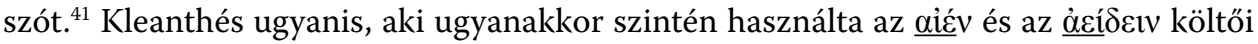
etimológiáját, sztoikus világnézetet népszerűsítő Zeus-himnuszában a halandó feladatát abban látja, hogy dicsőítse az istent, annak tetteit és a mögötte rejlő egyetemes és örök-

${ }^{36}$ N. Krevans felvetése szerint Xenophanés hatása sejthető az Aitia szerkezete mögött (Fighting against Antimachus: The Lyde and the Aitia Reconsidered. In: M. A. Harder - R. F. Regtuit - G. C. Wakker [edd.]: Callimachus. [Hellenistica Groningana 1] Groningen 1993. 151, 9. jegyz.). Ám állítását nem pontosítja, s tekintve, hogy Kallimachos főművének szerkezete is vitatott, és a filozófus-költő esete még bizonytalanabb, aligha lehetséges ebben az irányban a spekuláción továbbjutni.

37 Vö. Wilamowitz: i. m. (34. jegyz.) 2.

38 Cuypers: i. m. (16. jegyz.) 95-115.

39 Ezt a szembenállást a sztoikus morálfilozófiával erősíti a himnusz utolsó három sora is (94-96).

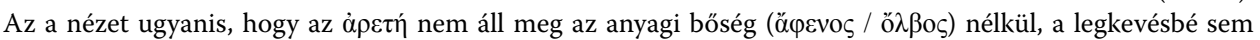
sztoikus, inkább peripatetikus. Ámbátor lehet, hogy Kallimachos a belső és külső gazdagság összefonódásával egyszerűen csak olyan irodalmi hagyományra utalt, mint a pindarosi (vö. P. 5. 1-4 és $\Sigma$ ad 1a [II 172 Drachmann], ahol Kallimachost párhuzamként idézik; további pindarosi helyekkel M. T. Smiley: Callimachus' Debt to Pindar and Others. Hermathena 18 [1914] 53).

40 A hellénisztikus költészet „filozófia utáni” jellegéhez vö. Snell: i. m. (3. jegyz.) 246: Nachphilosophisch sind diese Dichter, da sie nicht mehr daran glauben, daß man die Welt theoretisch meistern könne.

${ }^{41}$ Az isten megéneklésének és megragadásának lehetetlenségét nazianzosi Szent Gergely is sztoikusra

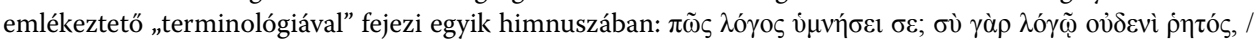

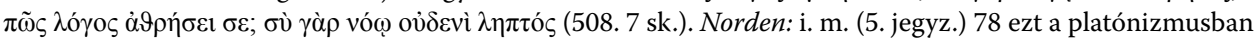
kimutatható gnósztikus hatás jeleként értelmezi. 


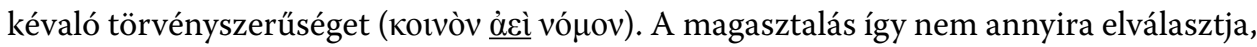
mint inkább összeköti az istent és az embert. Ezt a kölcsönösséget fejezi ki a $\tau \mu \eta ́$ és a

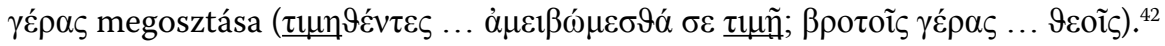

Cleanth. fr. 537 (h. Iov.) (von Arnim I 1905) 32-39:

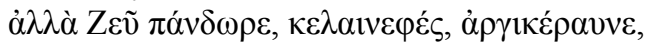

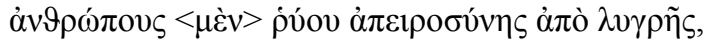

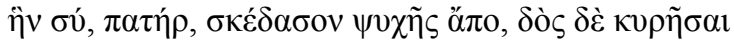

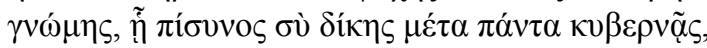

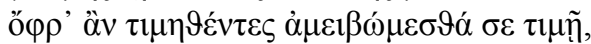

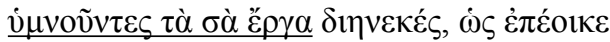

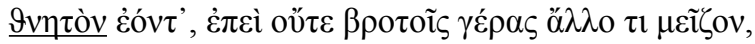

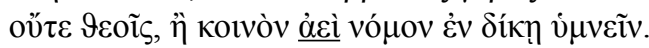

Kallimachos ezzel szemben az ember korlátaira, az istenségtől elválasztó szakadékra hívja fel a figyelmet, s ennek közlési módját Xenophanés idézetében találja meg, melyet minden orthodox filozófiai rendszertől függetlenül egy elterjedt himnikus toposz újraértelmezésére használ fel. Összegezve: Végső választ arra a kérdésre, miért idézte a költő Xenophanést, legalább annyira nem lehet adni, mint arra, miért írt himnuszokat. Ugyanis minden ilyen döntés, a müfaji kötöttségeken és konvenciószegéseken túl, alkotáspszichológiai motívumokkal terhelt, melyek végső soron felderíthetetlenek. Ezért a „miért”-re adott válasz helyett meg kell elégednünk a „hogyan?”, „milyen eszközökkel?” tisztázásával. Jelen dolgozat erre tett kísérletet.

\section{SUMMARY}

The following analysis is motivated by the new observation, that the epilogue of Callimachus's Hymn to Zeus (v. 91f.) contains an allusion to a fragment of the archaic poet-philosopher Xenophanes of Colophon (fr. 34.1f.). That this connection went unnoticed, may be explained by the fact, that the fragment of Xenophanes was preserved by several authors as a quotation with some verbal variations. Callimachus avails himself not of the version which could be considered the vulgata, but one preserved by Plutarch (de aud. poet. 2 . 17E). This observation being made we can set out to scrutinize the function of the allusion which seems to activate some generic conventions of hymnic poetry.

Keywords: Callimachus, Xenophanes, allusion, textual tradition, hymnic poetry

Adorjáni Zsolt

PPKE-BTK

Klasszika Filológia Tanszék

adorjanizs@gmail.com

42 Az isten és ember közösségének himnikus toposzához vö. Keyßner: i. m. (13. jegyz.) 69 sk. A költe-

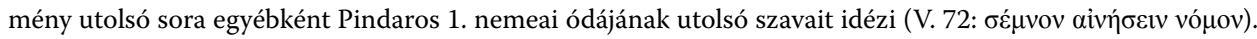

